Jonathan M. Karpoff

University of Washington, Seattle

M. Wayne Marr, Jr.

Clemson University

Morris G. Danielson

University of Washington, Seattle

\title{
Corporate Governance and Firm Performance
}

The Research Foundation of

The Institute of Chartered Financial Analysts 


\section{Research Foundation Publications}

Active Currency Management

by Murali Ramaswami

Analysts' Earnings Forecast Accuracy in Japan and the United States

by Robert M. Conroy, Robert S. Harris, and Young S. Park

Canadion Stocks, Bonds, Bills, and Infiation: 1950-1987

by James $\mathbf{E}$. Hatch and Robert E. White

Closed-Form Dusration Measures and Strategy Applications

by Nelson J. Lacey and Sanjay K. Nawalkha

Corporate Bond Rating Drift: An Examination of Credit Quality Rating Changes over Time

by Edward I. Altman and Duen Li Kao

Defawlt Risk, Mortality Rates, and the Performance of Corporate Bonds

by Edward I. Altman

Durations of Nondefault-Free Securities by Gerald $\mathrm{O}$. Bierwag and George $\mathrm{G}$. Kaufman

Earnings Forecasts and Share Price Reversals by Werner F.M. De Bondt

The Effect of Illiquidity on Bond Price Data: Some Symptoms and Remedies

by Oded Sarig and Arthur Warga

Equity Trading Costs

by Hans R. Stoll

Ethics, Faimess, Efficiency, and Financial Markets by Hersh Shefrin and Meir Statman

Ethics in the Investment Profession: A Survey by E. Theodore Veit, CFA, and Michael R. Murphy, CFA

The Founders of Modern Finance: Their Prize-Winning Concepts and 1990 Nobel Lectures

Franchise Value and the Price/Eamings Ratio by Martin L. Leibowitz and Stanley Kogelman
Fundamental Considerations in Cross-Border Investment: The European View

by Bruno Solnik

Global Asset Management and Performance Attribution by Denis S. Karnosky, and Brian D. Singer, CFA

Initial Public Offerings: The Role of Venture Capitalists by Joseph T. Lim and Anthony Saunders

Managed Futures and Their Role in Investment Portfolios by Don M. Chance, CFA

The Modern Role of Bond Covenants by Ileen $\mathrm{B}$. Malitz

A New Method for Valuing Treasury Bond Futures Options by Ehud I. Ronn and Robert R. Bliss, Jr.

A New Perspective on Asset Allocation by Martin L. Leibowitz

Options and Futures: $A$ Tutorial by Roger G. Clarke

The Poison Pill Anti-Takeover Defense: The Price of Strategic Deterrence

by Robert F. Bruner

A Practitioner's Guide to Factor Models

Predictable Time-Varying Components of International Asset Returns

by Bruno Solnik

Program Trading and Systematic Risk

by A.J. Senchack, Jr., and John D. Martin

The Role of Risk Tolerance in the Asset Allocation Process: A New Perspective by W.V. Harlow III, CFA, and Keith C Brown, CFA

Selecting Superior Securities by Marc R. Reinganum

Stock Market Structure, Volatility, and Volume by Hans R. Stoll and Robert E. Whaley

Stocks, Bonds, Bills, and Inflation:

Historical Retums (1926-1987)

by Roger G. Ibbotson and Rex A. Sinquefield

(Published with Irwin Professional Publishing) 


\section{Corporate Governance and Firm Performance}


(C) 1994 The Research Foundation of the Institute of Chartered Financial Analysts

All rights reserved. No part of this publication may be reproduced, stored in a retrieval system, or transmitted, in any form or by any means, electronic, mechanical, photocopying, recording, or otherwise, without the prior written permission of the copyright holder.

This publication is designed to provide accurate and authoritative information in regard to the subject matter covered. It is sold with the understanding that the publisher is not engaged in rendering legal, accounting, or other professional service. If legal advice or other expert assistance is required, the services of a competent professional should be sought.

ISBN 978-0-943205-80-9

Printed in the United States of America

December 1994 


\section{Mission}

The mission of the Research Foundation is to identify, fund, and publish research material that:

- expands the body of relevant and useful knowledge available to practitioners;

- assists practitioners in understanding and applying this knowledge; and

- enhances the investment management community's effectiveness in serving clients.

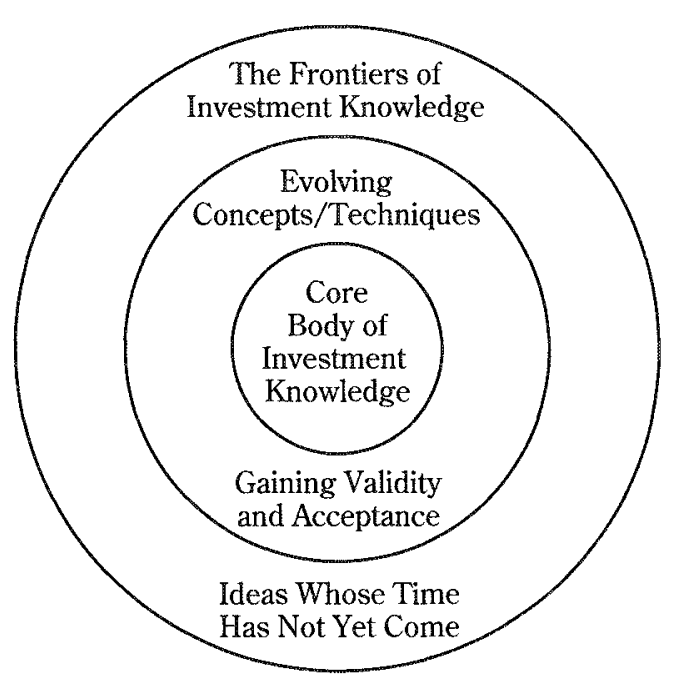

The Research Foundation of

The Institute of Chartered Financial Analysts

P.O. Box 3668

Charlottesville, Virginia 22903

U.S.A.

Telephone: 804/980-3644

Fax: 804/980-3634 


\section{Acknowledgments}

Completion of this work involved the support and encouragement of many. We thank the Research Foundation of the Institute of Chartered Financial Analysts for its financial support. We thank participants at seminars at the following institutions for helpful comments: Dartmouth College, The College of William and Mary, the Peter Drucker Management Center at Claremont College, Cornell University, the University of Houston, Texas A\&M University, and the University of Washington. Thanks also go to the Fifth Annual PACAP Conference and the 1994 Nanzan Finance Conference.

Jonathan M. Karpoff M. Wayne Marr, Jr. Morris G. Danielson 


\section{Foreword}

The market and investment analysts have many beliefs about what will benefit, harm, or destroy value in corporate investments. Sometimes, the beliefs are well grounded in what, in fact, happens in the future; sometimes, they are not. One of the beliefs the Street and analysts currently hold is that a company's corporate governance structure influences its financial performance. This belief is reflected in results: Many studies indicate that a company's stock price decreases when the company adds restrictions regarding corporate governance to its charter or bylaws. The reason commonly given that such a fall in stock price is warranted is that the restrictions decrease managers' accountability to shareholders and, therefore, injure the firm's long-term financial performance. Throughout the literature, however, little evidence exists either to confirm the deleterious effect of restrictions or disprove it.

In this study, Jonathan M. Karpoff, M. Wayne Marr, Jr., and Morris G. Danielson analyze the effect of 20 different governance provisions and provide some useful conclusions for practitioners. Their most important finding is that, indeed, companies with the fewest restrictive provisions relative to other companies in their industries have the best industry-adjusted performance. Of particular note is their finding that poison pills have apparently the most injurious effect on future firm performance.

The Research Foundation of the Institute of Chartered Financial Analysts is pleased to offer you this crisp analysis of the connection between corporate governance restrictions and firm performance. We hope the conclusions will be useful to your prognoses of firm value.

Katrina F. Sherrerd, CFA Acting Research Director and Chief Operating Officer

The Research Foundation of

The Institute of Chartered Financial Analysts 


\section{Corporate Governance and Firm Performance}

Does a company's corporate governance structure influence its financial performance? The results of many event studies indicate that, on average, a firm's stock price decreases when its corporate governance structure becomes more restrictive. Examples include the adoption of certain charter amendments (Jarrell and Poulsen 1987, Bhagat and Jeffries 1991), poison pills (Malatesta and Walkling 1988, Ryngaert 1988, Bruner 1991), and state takeover laws (Karpoff and Malatesta 1989). A common conclusion of these studies is that a restrictive governance structure decreases managers' accountability to shareholders, which is expected to harm the firm's long-term financial performance. There is little direct evidence, however, on the actual performance effects of corporate governance provisions. ${ }^{1}$

We examined the correlations between corporate governance structure and two measures of performance: return on assets (ROA) and market-bookvalue ratio $(\mathrm{M} / \mathrm{B})$. Our tests exploited an unusual data base compiled by Institutional Shareholder Services, Inc. (ISS), which contains comprehensive governance profiles for the Standard \& Poor's 500 Index. The data indicate whether or not a firm has each of 20 different governance provisions and the year each provision was adopted. The provisions include 15 firm-level provisions, such as poison pills, and five types of state antitakeover laws.

We found that cross-sectional performance is related to a simple index of the restrictiveness of a firm's governance structure. Our major finding was that firms with the fewest restrictive provisions relative to other firms in their industries have the best industry-adjusted performance.

We also found that the correlations between specific corporate governance provisions and firm performance depend on the type of provision. Our most

\footnotetext{
${ }^{1}$ As an exception, Gordon and Pound (1992) found weak evidence that firms enacting a large number of new governance protections have higher average cash flow measures and lower market valuation ratios than their industry peers. They interpreted their results as indicating that restrictive governance provisions protect managers in firms with free-cash-flow agency problems.
} 
consistent finding was that the existence of a poison pill is negatively related to industry-adjusted measures of ROA and M/B. Furthermore, the negative correlation appears to follow the adoption of a pill, becoming stronger the longer the pill is in place.

\section{Corporate Governance Provisions}

Our empirical tests are based on the corporate governance provisions detailed in the Appendix. These provisions are grouped into four categories. The primary criterion used to classify provisions is the Manne (1965) distinction between the external and internal markets for corporate control. The external market for corporate control refers to actions such as tender offers that outside bidders take to gain control through the accumulation of a large block of shares. The internal market for corporate control refers to actions such as proxy challenges that current shareholders take to influence corporate policy by exercising voting rights. The other two categories of provisions are state antitakeover laws and provisions that ISS designated as potentially favorable for investors. ${ }^{2}$

- Extemal control mechanisms are those that directly impede or may be used to impede hostile acquisitions and that work primarily through their effects on the external market for control. The provisions in this category are poison pills, blank-check preferred stock, and stakeholder charter clauses. Previous studies have reported that, on average, the stock price change upon the announcement of these provisions is negative. ${ }^{3}$

- Internal control mechanisms are those that increase a large shareholder's cost of exercising control or influencing corporate policies and that directly affect the internal market for control. This category consists of classified boards, fair price provisions, recent (within three years) reincorporation to Delaware, shareholder meeting requirements, unequal voting rights,

${ }^{2}$ All defensive governance provisions impede unsolicited bids for control, and the effects of any one provision are firm specific and difficult to unravel. Thus, some readers may dispute our choice of categories and inclusion of specific provisions within certain categories. The grouping was not done haphazardly, however. In constructing the categories, we conferred with institutional investors and their advisors at ISS. ISS is in the business of selling information on governance provisions to institutional investors. Therefore, the principals at ISS have direct incentive to be well informed about the effects of the various governance provisions on the market for corporate control.

${ }^{3}$ For poison pills, see Malatesta and Walkling (1988) and Ryngaert (1988); for blank-check preferred stock, see Jarrell and Poulsen (1987). We are unaware of any empirical examination of stakeholder charter provisions, although Alexander, Marr, and Spivey (1993) reported that state laws that mimic the language of such provisions are associated with negative and statistically significant stock returns for affected companies. 
supermajority voting requirements, and recent (within three years) elimination of cumulative voting. Unlike external control mechanisms, these provisions do not directly affect a bidder's cost of accumulating a large block of stock. By imposing costs on large shareholders, however, internal mechanisms also can impede external bids for control. ${ }^{4}$

- State takeover laws include control share acquisition laws, fair price laws, freeze-out laws, cash-out laws, and poison pill laws. By 1992, 39 states had adopted a total of 110 of these laws, which together cover most of the large corporations in the United States. The laws impose restrictions on both internal and external control mechanisms. For example, poison pill laws provide statutory sanction for poison pills, thereby strengthening the legal position of a firm adopting a poison pill. Control share acquisition laws and freeze-out laws do not directly impede the accumulation of a large block of stock, but each can be used to prevent a large outside shareholder from exercising control over corporate resources.

- Provisions that ISS designates as potentially favorable for investors include antigreenmail, confidential voting, and cumulative voting provisions; provisions that indemnify company directors and officers from personal liability for corporate actions; and an indicator variable for firms that opted out of coverage by a state antitakeover law. Unlike provisions in the other categories, these provisions may increase managers' vulnerability to unsolicited takeover bids. We thus did not include these provisions in computing an index of firms' corporate governance restrictiveness, but we did investigate the correlations between these provisions and firm performance.

Table 1 reports on the frequencies of each governance provision in the sample for each year of the 1984-89 period. The average number of all provisions increased from 2.14 per firm in 1984 to 5.94 per firm in 1989. Blank-check preferred stock, classified boards, fair-price charter provisions, shareholder meeting requirements, and supermajority vote requirements were all widely adopted by 1989 . The use of poison pills and director/officer liability indemnity provisions also increased substantially, as did coverage by state freeze-out, control share acquisition, and poison pill laws.

Many of these provisions were adopted after important court decisions upheld their validity or increased the provision's benefits. For example, increased use of poison pills followed a Delaware Supreme Court decision (Moran v. Household International, 500 A. 2d 1346, Del. 1985) that upheld the

\footnotetext{
${ }^{4}$ As explained in the Appendix, reincorporations to Delaware are included in this category because many such reincorporations are done to acquire classified boards (which are prohibited in some other states) or for protection under Delaware's freeze-out law.
} 


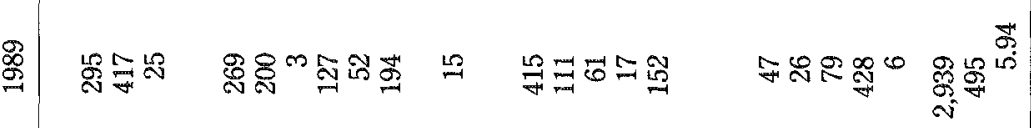

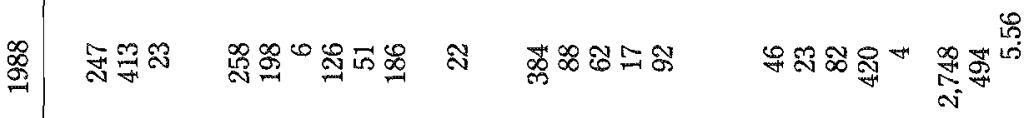

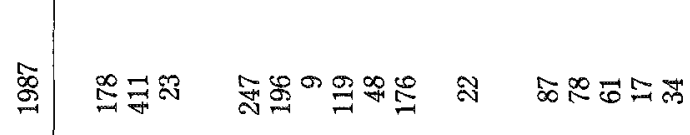

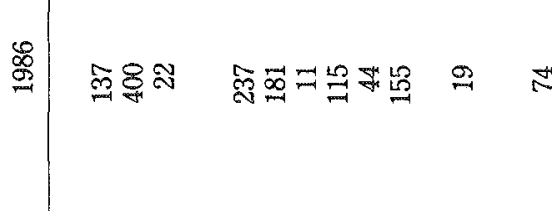

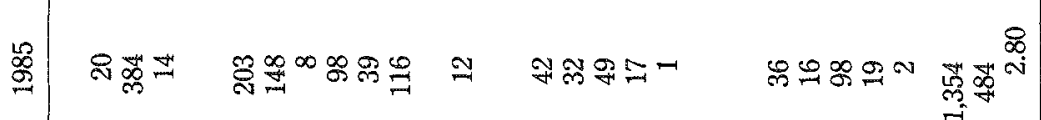

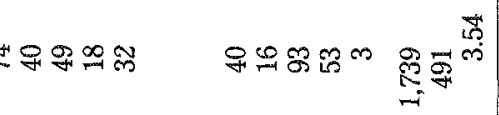
$\stackrel{0}{*}$

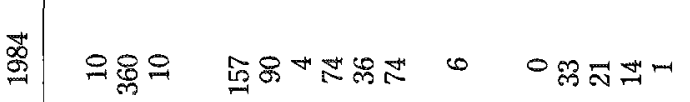

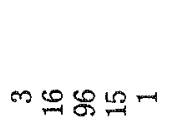
$-\infty \underset{i}{*}$

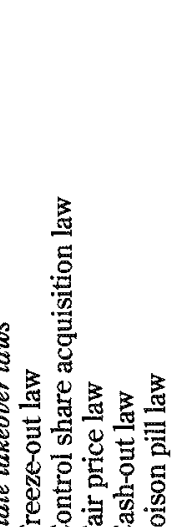

芯 
use of a poison pill takeover defense. Many firms adopted director/officer liability indemnity provisions after another Delaware Supreme Court decision (Smith v. Van Gorkom, 488 A. 2d 858, Del. 1985) greatly expanded the types of corporate decisions for which officers and directors could be held personally liable. State takeover laws became widespread after the U.S. Supreme Court upheld Indiana's control share acquisition law, creating the presumption that other takeover laws also were valid (CTS v. Dynamics Corp. of America, $107 \mathrm{~S}$. Ct. 1673, 1987). The largest increase in state law coverage occurred when Delaware adopted a freeze-out law in 1988.

The firms in our sample exhibited no standard or boilerplate governance structure. The 495 firms in the 1989 sample, for example, had 320 different combinations of the 20 governance provisions.

\section{Governance Provisions and Firm Performance}

All of the provisions listed in the Appendix (with the possible exception of director/officer liability indemnity) affect an outsider's cost of obtaining corporate control or influencing corporate policies. Therefore, the managerial entrenchment and stockholders' interest hypotheses apply to these provisions. Unlike event study applications, however, a firm's governance provisions can affect, or be affected by, performance. Our measures of firm performance are ROA and $\mathrm{M} / \mathrm{B}$. ROA reflects the annual measured return to the historical value of all net investments a firm has made. $\mathrm{M} / \mathrm{B}$ reflects the investors' estimate of the premium of a firm's cash flow capabilities over the historical value of the firm's investments. To the extent that book values reflect replacement costs, $M / B$ is a proxy for Tobin's $q .{ }^{5}$

The Entrenchment and Stockholders' interest Hypotheses. We investigated three hypotheses about how various factors affect firm performance as measured by ROA and M/B. Predictions based on these hypotheses can be summarized as follows:

\section{Hypothesis}

Managerial entrenchment

Stockholders' interest-improved performance

Stockholders' interest-no performance effect

$\begin{array}{cc}\text { Effect on ROA } & \text { Effect on } M / B \\ \text { Negative } & \text { Negative } \\ \text { Positive } & \text { Positive } \\ \text { None } & \text { Positive }\end{array}$

\footnotetext{
${ }^{5}$ Tobin's $q$ is the ratio of the market value of a firm to its replacement cost.
} 
Managerial entrenchment. The managerial entrenchment hypothesis implies that governance provisions that increase outside bidders' costs of obtaining and exercising control serve to insulate managers from market discipline for poor performance. This insulation can prevent investors from removing a managerial team they consider inefficient, or it may allow an otherwise efficient managerial team to consume more perquisites than it otherwise would. The most important perquisites may be simply leisure and the ability to act without the threat of swift accountability for poor decisions. In short, the entrenchment hypothesis implies that a restrictive provision works to decrease managerial diligence and firm performance. ROA, which reflects current financial performance, and $\mathrm{M} / \mathrm{B}$, which reflects investors' expectations about future performance, should both correlate negatively with the existence of a restrictive provision.

- Stockholders' interest-improved performance. The stockholders' interest hypothesis, in contrast to managerial entrenchment, implies that restrictive governance provisions work to improve firm performance. In one form of the hypothesis, restrictions on outside takeover reduce the incidence of frivolous or destructive bids for control. ${ }^{6}$ According to this hypothesis, the threat of outside takeover serves primarily to divert managerial attention from core business activities. In a second form of the hypothesis, the threat of takeover discourages profitable investment that is incorrectly undervalued in the financial market? ${ }^{7}$ Under either form, provisions that insulate managers from outside influence allow managers to focus on improving long-run business performance. Thus, this restrictive provision should serve to increase both $\mathrm{ROA}$ and $\mathrm{M} / \mathrm{B}$.

- Stockholders' interest-no performance effect. In another form of the stockholders' interest hypothesis, restrictive governance provisions mitigate a shareholder free-rider problem. ${ }^{8}$ Without these provisions, individual stockholders have incentive to tender their shares to a bidder even though they could obtain a higher price if they collectively withheld their shares. The provisions encourage bidders for control to deal directly with managers who, acting as shareholders' agents, can negotiate a higher takeover premium than would have been achieved otherwise. Under this hypothesis, the governance provisions change the expected takeover premium and, therefore, firm value. The provisions do not affect the firms' operations or internal efficiency, how-

\footnotetext{
${ }^{6}$ Wallman (1990).

${ }^{7}$ See Pound and Jarrell (1988) and Lipton and Rosenblum (1991).

${ }^{8}$ See DeAngelo and Rice (1983).
} 
ever, and thus have no effect on current profitability. A restrictive provision should not affect ROA but should be positively correlated with M/B.

Timing and Endogeneity. The managerial entrenchment and both forms of the stockholders' interest hypotheses yield clear predictions about the announcement-period stock price effects of restrictive governance provisions. For the reasons discussed below, however, they yield ambiguous predictions about cross-sectional differences in the financial performance of the affected firms.

- Timing of the effect. Semistrong-form market efficiency provides a theoretical basis for selecting the window in which to test the valuation effect of a governance provision's public announcement. Event study tests, therefore, are joint tests of market efficiency and the specific hypothesis in question.

We are unaware of any similar standard to identify the appropriate period in which a governance provision may affect ROA. According to the entrenchment hypothesis, a poison pill decreases managers' diligence and firm performance, but the hypothesis is consistent with the poor ROA performance showing up immediately, one year from adoption, or even ten years from adoption.

Through most of the empirical tests, we assume that any effect of a provision on firm performance appears immediately upon adoption. Under the entrenchment hypothesis, for example, a poison pill's deleterious effect on managerial performance is assumed to affect the firm in each year the pill is in effect and in no other years. Thus, our empirical procedures yield joint tests of this timing assumption and the central hypotheses regarding managerial entrenchment and stockholders' interest. This timing assumption is plausible when performance is proxied by $\mathrm{M} / \mathrm{B}$ (which reflects market values) but less so for ROA (which does not reflect market values).

- Endogeneity and causality. Demsetz and Lehn (1985) argued that competition encourages firms to gravitate toward the specific ownership structure that increases their chances of survival. Like ownership structure, a firm's corporate governance structure also may be determined endogenously by the firm's business conditions. A firm's use of any specific provision may reflect its efforts to adjust optimally to its competitive environment.

Because of this endogeneity, an unwary researcher may reverse the causality between governance provisions and financial performance. For example, firms in a declining industry may adopt poison pills because the pills provide managers with leverage to negotiate higher prices in the case of takeover. If so, the observation that poison pills exist when firms perform poorly would not reflect entrenchment but, rather, the second form of the 
stockholders' interest hypothesis.

Because of the endogenous nature of our variables of concern, one can interpret the data as describing the correlations between governance provisions and firm performance. To interpret the results of our statistical procedures as hypotheses tests requires an extra assumption. We assume that the business conditions that affect a firm's decision to use a particular provision affect all firms in the same industry in the same way. Therefore, we adjusted each firm's performance and governance measures by the relevant industry averages. Our empirical tests measure the extent to which the difference in a firm's performance from that of the industry average is explained by the difference in the firm's corporate governance position from its industry average.

Specifically, industry-adjusted ROA for firm $i$ in year $t\left(\mathrm{ROA}_{i, t}^{a}\right)$ is defined as

$$
\operatorname{ROA}_{i, t}^{a}=\frac{\operatorname{ROA}_{i, t}-\overline{\mathrm{ROA}}_{I, t}}{S_{I, t}},
$$

where $\mathrm{ROA}_{i, t}$ is firm $i$ 's ROA measured at the fiscal year-end, $t ; \overline{\mathrm{ROA}}_{I, t}$ is the mean ROA among firms in the same industry for the same year; and $S_{l, t}$ is the cross-sectional standard deviation of ROAs among all firms in the same industry, $I$, in year $t$. All continuous variables used in the empirical tests are adjusted similarly.

Indicator variables for the existence of specific governance provisions also are adjusted. The industry-adjusted poison pill variable for firm $i$ in year $t$ is

$$
\mathrm{PP}_{i, t}^{a}=\mathrm{PP}_{i, t}-\overline{\mathrm{PP}}_{I, t},
$$

where $\mathrm{PP}_{i, t}$ is an indicator variable set equal to 1 if firm $i$ has a poison pill in place at the end of year $t$ and $\overline{\mathrm{PP}}_{I, t}$ is the percentage of firms with poison pills in industry $I$ at the end of year $t$.

Adjusting all variables by industry averages provides a control for effects on the variables that are related to business conditions. Thus, the presence of a poison pill is particularly noteworthy, and weighted in the empirical tests, when most other firms in the same industry do not have poison pills. In an industry in which most firms do have poison pills, the presence of a poison pill may simply reflect business conditions in that industry. Accordingly, the poison pill receives little weight in the empirical tests.

To construct industry means, the firms in the sample are partitioned into 
industries based on two-digit SIC numbers taken from the 1993 Compustat File. ${ }^{9}$ A number of two-digit industries contained fewer than nine firms. In such cases, we grouped firms from adjacent two-digit codes into a single industry so that each industry group has a minimum of nine firms. ${ }^{10}$ This partitioning procedure resulted in all firms being grouped into 25 industries.

Analysis of variance tests revealed evidence of significant industry clustering of four provisions in our sample: poison pills, blank-check preferred stock, confidential voting, and cumulative voting. For these provisions, at least, the industry adjustment tends to remove the influence on the adoption decision that comes from underlying business conditions.

The industry-adjustment process can remove the correlations we seek to measure. Suppose, for example, that the entrenchment hypothesis is true. An industry in which poison pills are common would then tend to be characterized by low average performance. Because the performance and poison pill measures both are adjusted for the industry mean, however, we would likely observe little correlation between poison pills and performance. The industryadjustment procedure, therefore, can bias results toward accepting the null hypothesis of no relation between governance provisions and performance.

- Additional assumptions. The managerial entrenchment and stockholders' interest hypotheses, so well suited for tests using event study methods, yield ambiguous predictions when applied to an investigation of firm performance. We used the following assumptions to derive testable implications using the entrenchment and stockholders' interest hypotheses:

- Any effect of a corporate governance provision on firm performance begins immediately upon adoption of the provision.

- Business conditions that encourage or discourage the application of a specific governance provision apply equally to all firms in the same industry.

\section{The Corporate Governance Index and Firm Performance}

ISS distinguishes between the provisions in the Appendix that fall in Categories 1 to 3 , which it labels "negative" provisions, and those in Category 4, which it labels "positive." We rely on the ISS distinctions for the tests in this

\footnotetext{
${ }^{9}$ Because the Compustat data are incomplete for some of the firms, the final sample size ranges from a low of 478 firms in 1984 to a high of 495 firms in 1989.

${ }^{10} \mathrm{We}$ originally required a minimum of ten firms per industry but changed the minimum to nine to accommodate several two-digit industries with exactly nine firms. The results are not affected substantially if the industries are redefined to require a minimum of ten firms per industry.
} 
section and define the corporate governance index as the number of "negative" provisions that were in place for a given year. Firm $i$ 's industry-adjusted corporate governance index for year $t, \mathrm{CGI}_{i, t}^{a}$, is defined as

$$
\mathrm{CGI}_{i, t}^{a}=\mathrm{CGI}_{i, t}-\overline{\mathrm{CGI}}_{I, t} \text {, }
$$

where $\mathrm{CGI}_{i, t}$ is the firm's raw index value and $\overline{\mathrm{CGI}}_{\mathrm{I}, \mathrm{t}}$ is the mean index value for all firms in the same industry.

To examine the relationship between $\mathrm{CGI}_{i, t}^{a}$ and firm performance, we partitioned the firms into three groups for each year based on each firm's $\mathrm{CGI}_{i, t}^{a}$ value. The groups are

\section{Group Description}

Liberal governance structure

Average governance structure

Restrictive governance structure

$$
\begin{aligned}
& \text { Value of } \mathrm{CGI}_{i, t}^{a} \\
& -1.5>\mathrm{CGI}_{i, t}^{a} \\
& 1.5 \geq \mathrm{CGI}_{i, t}^{a} \geq-1.5 \\
& \mathrm{CGI}_{i, t}^{a}>1.5
\end{aligned}
$$

The first measure of performance examined is industry-adjusted return on assets $\left(\mathrm{ROA}_{i, t}^{a}\right)$. A firm's raw return on assets, $\mathrm{ROA}_{i, t}$, is defined as net income plus interest expense divided by the book value of assets. ${ }^{11}$

$\mathrm{ROA}_{i, t}^{a}$ was calculated from $\mathrm{ROA}_{i, t}$ using Equation 1 . The mean $\mathrm{ROA}_{i, t}^{a}$ was calculated within each of the three groups $(g=1,2,3)$ for each year:

$$
\overline{\mathrm{ROA}}_{g, t}^{a}=\frac{\sum_{i=1}^{n_{s t}} \mathrm{ROA}_{i t}^{a}}{n_{g t}},
$$

where $i \in g$, and $n_{g t}$ is the number of firms in group $g$ for year $t$. To draw general inferences from the six annual cross-sectional patterns for 1984 to 1989 , the time series mean was calculated for each group, $g$.

$$
\overline{\mathrm{ROA}}_{g}^{a}=\frac{\sum_{t=84}^{89} \overline{\mathrm{ROA}}_{g, t}^{a}}{6} .
$$
\#6.

${ }^{11}$ The relationship is the sum of Compustat items \#172 and \#15 divided by Compustat item 
Under the assumption that the $\overline{\mathrm{ROA}}_{g, t}^{a}$ are distributed identically and independently,

$$
\tau_{g}=\frac{\overline{\mathrm{ROA}}_{\mathrm{g}}^{a}}{s_{g} / \sqrt{6-1}}
$$

is distributed as a student- $t$ random variable with five degrees of freedom, where $s_{g}$ is the standard deviation of the time series $\overline{\mathrm{ROA}}_{g, t}^{a}$

The second measure of performance is the firm's industry-adjusted $\mathrm{M} / \mathrm{B}$ $\left(\mathrm{M} / \mathrm{B}_{i, t}^{a}\right)$. A firm's raw $\mathrm{M} / \mathrm{B}, \mathrm{M} / \mathrm{B}_{i, t}$, is defined as the sum of the year-end market value of common stock plus the book value of debt, divided by the book value of assets. The industry-adjusted value, $M / B_{i, t}^{a}$, the annual group means, and the time-series means are calculated in the same manner as for $\operatorname{ROA}_{i, t}^{a}{ }^{12}$

Table 2 reports the overall group mean $\mathrm{ROA}$ and $\mathrm{M} / \mathrm{B}$ values for each of the three governance structure groups. The highest mean performance is associated with firms that have the least restrictive governance structures. For this group, $\overline{\mathrm{ROA}}_{g}^{a}=0.1497$ with a $t$-statistic of 3.26 and $\overline{\mathrm{M}} / \overline{\mathrm{B}}_{g}^{a}=0.2445$ with a $t$-statistic of 6.94 . Firms with more restrictive governance structures have lower measures of performance. For those with roughly the same number of restrictive provisions as their industry averages, $\overline{\mathrm{ROA}}_{g}^{a}=-0.0233(t=-1.93)$ and $\overline{\mathrm{M} / \mathrm{B}_{g}} a=-0.0630(t=-4.87)$. For firms with the most restrictive structures, $\overline{\mathrm{ROA}}_{g}^{a}=-0.0328(t=-1.18)$ and $\overline{\mathrm{M} / \mathrm{B}_{g}^{a}}=0.0054(t=0.13)$.

These results are consistent with the managerial entrenchment hypothesis. Firms with the most liberal governance structures have the highest financial performance, as measured by ROA. These firms' assets are also valued relatively highly by investors, as reflected in their high $M / B s$.

\section{Performance Correlations by Provision}

We also examined the effects of individual provisions on performance. Ordinary-least-squares regressions were estimated with $\mathrm{ROA}_{i, t}^{a}$ (or $\left.\mathrm{M} / \mathrm{B}_{i, t}^{a}\right)$ as the dependent variable. The regressors consisted of two control variables and all 20 corporate governance variables. Separate regressions were estimated using cross-sectional data on all companies in the sample for each year during

\footnotetext{
${ }^{12}$ Referring to Compustat items, $M / \mathrm{B}_{i, t}$ is calculated as (Item \#25 $\times$ Item \#24) + Item \#6 - Item \#60, Item \#6
}

all defined for year $t$. 
Table 2. Mean Values of Industry-Adjusted ROA and M/B

\begin{tabular}{lcc}
\hline Group & $\begin{array}{c}\text { Industry- } \\
\text { Adjusted ROA }\end{array}$ & $\begin{array}{c}\text { Industry- } \\
\text { Adjusted M/B }\end{array}$ \\
\hline $\begin{array}{l}\text { Liberal governance structure }\left(-1.5>\mathrm{CGI}_{i, t}^{a}\right) \\
\text { Mean number of firms }=83.2\end{array}$ & & \\
$\begin{array}{l}\text { Mean industry-adjusted performance } \\
t \text {-statistic }\end{array}$ & 0.1497 & 0.2445 \\
$\begin{array}{l}\text { Average governance structure }\left(1.5 \geq \mathrm{CGI}_{i, t}^{a} \geq-1.5\right) \\
\text { Mean number of firms }=315.3\end{array}$ & $3.26^{*}$ & $6.94^{*}$ \\
$\begin{array}{l}\text { Mean industry-adjusted performance } \\
t \text {-statistic }\end{array}$ & -0.0233 & \\
Restrictive governance structure $\left(\mathrm{CGI}_{i, t}^{a}>1.5\right)$ & -1.93 & -0.0630 \\
Mean number of firms = 90.5 & & $-4.87^{*}$ \\
Mean industry-adjusted performance & & \\
$t$-statistic & -0.0328 & 0.0054 \\
\hline
\end{tabular}

Note: Mean values of industry-adjusted ROA and M/B are for groups of firms partitioned by the industryadjusted corporate governance index, 1984-89. The index measures the overall restrictiveness of a firm's corporate governance structure. Each firm's raw index is the sum of the number of "negative" provisions the firm has, as determined by Institutional Shareholders Services, Inc. The firm's industry-adjusted corporate governance index, $\mathrm{CGI}_{i, t}^{q}$, is equal to the difference between the firm's raw index and the mean raw index value for all firms in the same industry for the year. Firms are partitioned by $\mathrm{CGI}_{i, t}^{q}$ each year.

*Reject the null hypothesis that the mean equals zero in favor of the alternative that it does not equal zero with a probability of a Type I error equal to or less than 0.10 .

the 1984-89 period.

The control variables measure the effects of firm size and leverage on $\mathrm{ROA}_{i, t}^{a}$ (or $\mathrm{M} / \mathrm{B}_{i, t}^{a}$ ). Firm size is measured as the market value of equity at year-end plus the book value of debt. Leverage is measured as the book value of debt divided by the book value of assets. Both control variables were adjusted for the industry mean and standard deviation, as described for $\mathrm{ROA}_{i, t}^{a}$ in Equation 1. Also, all corporate governance variables were adjusted for the firm's industry mean, as described for poison pills in Equation 2.

The null hypothesis for each governance variable is that its coefficient is zero. To derive inferences using of all six years' results, we computed the mean estimator for each governance coefficient, $k$, using the following equation:

$$
\hat{\beta}_{k}=\frac{\sum_{t=84}^{89} \hat{\beta}_{k t}}{6},
$$

where $\hat{\beta}_{k t}$ is the estimated coefficient for provision $k$ in year $t$. Under the null 
hypothesis that the provision has no effect on performance, $\widehat{\beta}_{k}=0$. To test the null hypothesis against the alternative that $\hat{\beta}_{k} \neq 0$, the following test statistic was computed:

$$
\tau_{k}=\frac{\hat{\beta}_{k}}{s_{k} / \sqrt{6-1}},
$$

In Equation $8, s_{k}$ is the standard deviation of the six yearly estimators $\hat{\beta}_{k *}$ Under the null hypothesis that $\mathrm{ROA}_{i, t}^{a}$ (or $\mathrm{M} / \mathrm{B}_{i, t}^{a}$ ) is not correlated with the provision $k$ and that the $\hat{\beta}_{k t}$ are distributed independently and identically, $\tau_{k t}$ has a $t$ distribution with five degrees of freedom.

Our findings are summarized in Table 3. As an expositional aid, the regressors are organized by the categories introduced in the Appendix and Table 1.

- External control mechanisms. The presence of a poison pill is negatively correlated with industry-adjusted ROA $\left(\hat{\beta}_{k}=-0.1025, \tau_{k}=-2.19\right)$ and with $\mathrm{M} / \mathrm{B}\left(\beta_{k}=-0.1795, \tau_{k}=-2.96\right)$. Blank-check preferred stock is also associated with low ROA $\left(\hat{\beta}_{k}^{k}=-0.1950, \tau_{k}=-11.57\right)$ and M/B $\left(\hat{\beta}_{k}=-0.2883, \tau_{k}\right.$ $=-10.24$ ). For stakeholder provisions, the mean estimators are positive but with a relatively low $t$-statistic for $\mathrm{M} / \mathrm{B}_{i, t}^{a}$.

The poison pills and blank-check preferred stock findings are consistent with the managerial entrenchment hypothesis. The results for stakeholder clauses, in contrast, are weakly consistent with the first form of the stockholders' interest hypothesis. We attempted to unravel these seemingly contradictory results in several tests. As reported below, only the poison pill result is robust to alternate specifications.

- Internal control mechanisms. For fair price provisions and supermajority vote requirements, the results are consistent with the second form of the stockholders' interest hypothesis. In each case, the mean coefficient in the $\mathrm{ROA}_{i, t}^{a}$ regression is not significantly different from zero at normal levels but is positive and significant at the 5 percent level in the $M / \mathrm{B}_{i, t}^{a}$ regression. These results are consistent with the hypothesis that fair price and supermajority provisions have little effect on current financial performance but increase expected takeover premiums.

The mean coefficients for the other provisions in this category are not consistent with any of the three hypotheses. The existence of a classified board is associated with poor $\mathrm{ROA}_{i, t}^{a}$ performance but is not significantly related to $M / B_{i, t}^{a}$. Unequal voting rights are positively correlated with ROA but insignificantly associated with $\mathrm{M} / \mathrm{B}$. 
Table 3. Mean Estimated Coefficients from Cross-Sectional Ordinary-Least-Squares Regressions for Each Year, 1984-89

\begin{tabular}{|c|c|c|c|c|}
\hline \multirow[b]{2}{*}{ Provision } & \multicolumn{2}{|c|}{ Industry-Adjusted ROA } & \multicolumn{2}{|c|}{ Industry-Adjusted $\mathrm{M} / \mathrm{B}$} \\
\hline & $\begin{array}{l}\text { Mean } \\
\text { Estimator }\end{array}$ & $t$-statistic & $\begin{array}{l}\text { Mean } \\
\text { Estimator }\end{array}$ & $t$-statistic \\
\hline \multicolumn{5}{|l|}{ External control mechanisms } \\
\hline Poison pill & -0.1025 & $-2.19^{\star}$ & -0.1795 & $-2.96^{*}$ \\
\hline Blank-check preferred stock & -0.1950 & $-11.57^{*}$ & -0.2883 & $-10.24^{*}$ \\
\hline Stakeholder clause & 0.1933 & $3.88^{*}$ & 0.0510 & 1.49 \\
\hline \multicolumn{5}{|l|}{ Internal control mechanisms } \\
\hline Classified board & -0.0625 & $-3.72^{*}$ & 0.0026 & 0.14 \\
\hline Fair price provision & 0.0793 & 1.80 & 0.0751 & $6.15^{\star}$ \\
\hline Firm reincorporated to Delaware & 0.1645 & 0.58 & 0.3989 & 1.02 \\
\hline Supermajority vote requirement & -0.0402 & -0.63 & 0.0867 & $3.76^{\star}$ \\
\hline Unequal voting rights & 0.1334 & $5.57^{\star}$ & -0.0030 & -0.09 \\
\hline Shareholder meeting requirements & 0.0740 & 1.27 & 0.0232 & 0.85 \\
\hline $\begin{array}{l}\text { Firm eliminated cumulative voting } \\
\text { or right to alter board size }\end{array}$ & -0.0357 & -0.51 & -0.0635 & -0.66 \\
\hline \multicolumn{5}{|l|}{ State takeover laws } \\
\hline Freeze-out law & 0.0385 & 0.63 & 0.0590 & 1.47 \\
\hline Control share acquisition law & 0.0833 & 0.87 & -0.0928 & -1.12 \\
\hline Fair price law & -0.0926 & -1.89 & -0.0921 & -1.95 \\
\hline Cash-out law & -0.0399 & -0.86 & -0.2184 & $-4.02^{*}$ \\
\hline Poison pill law & -0.3968 & -1.31 & -0.1300 & -1.69 \\
\hline \multicolumn{5}{|l|}{$\begin{array}{l}\text { Provisions that ISS designates as } \\
\text { potentially favorable for investors }\end{array}$} \\
\hline Antigreenmail provision & -0.1412 & -1.72 & -0.0200 & 0.33 \\
\hline Confidential voting & -0.2187 & $-5.20^{*}$ & -0.8097 & $-7.92^{*}$ \\
\hline Cumulative voting & -0.0507 & -1.16 & 0.0995 & $3.22^{\star}$ \\
\hline \multicolumn{5}{|l|}{ Director/officer liability } \\
\hline \multicolumn{5}{|l|}{ Firm opted out of state takeover } \\
\hline law & -0.7808 & $-6.41^{\star}$ & 0.0164 & 0.08 \\
\hline \multicolumn{5}{|l|}{ Control variables } \\
\hline Market value of assets & 0.1365 & $6.83^{\star}$ & 0.1065 & $5.50^{*}$ \\
\hline Debt/assets (book values) & -0.2733 & $-7.75^{*}$ & -0.3591 & $-14.83^{\star}$ \\
\hline Mean number of observations & \multicolumn{2}{|c|}{489} & \multicolumn{2}{|c|}{489} \\
\hline Mean adjusted $R^{2}$ & \multicolumn{2}{|c|}{0.114} & \multicolumn{2}{|c|}{0.170} \\
\hline
\end{tabular}

Note: Each regressor also is adjusted by the firm's industry average value of the variable. The mean estimators and $t$-statistics are computed from the time series of cross-sectional coefficients for each regressor.

* Reject the null hypothesis that the mean coefficient equals zero in favor of the alternative that it does not equal zero with a probability of a Type I error equal to or less than 0.10 . 
State takeover laws. The mean coefficient for cash-out laws is negative in the $\mathrm{M} / \mathrm{B}_{i, t}^{a}$ regressions, but the $\mathrm{ROA}_{i, t}^{a}$ coefficient is not significantly different from zero. The mean coefficients for fair price laws and poison pill laws are negative for both $\mathrm{ROA}_{i, t}^{a}$ and $\mathrm{M} / \mathrm{B}_{i, t}^{a}$, consistent with the managerial entrenchment hypothesis. In both cases, however, the test statistics are small.

- ISS-designated potentially investor-favorable provisions. Although ISS considers these provisions to be favorable to investors, the regression results are mixed. Liability indemnity for officers and directors is positively correlated with both $\mathrm{ROA}_{i, t}^{a}$ and $\mathrm{M} / \mathrm{B}_{i, t}^{a}$. We believe, however, that this finding reflects primarily the availability of indemnity insurance to financially healthy firms. According to Table 1, most firms in the sample adopted indemnity provisions in the late 1980s. As reported by Brook and Rao (1994), such provisions are adopted almost exclusively by firms that purchase indemnity insurance, which in turn, is offered primarily to financially healthy firms. As a result, we believe that our results for indemnity provisions reflect a selection bias toward financially strong firms, for which our industry-adjustment procedure only partly controls. This conclusion is consistent with the results of sensitivity tests reported in the next section.

Two provisions-confidential voting and the decision to opt out of coverage by a state antitakeover law-are negatively associated with $\mathrm{ROA}_{i, b}^{a}$; confidential voting also is negatively associated with $\mathrm{M} / \mathrm{B}_{i, t^{*}}^{a}$

\section{Poison Pills and Blank-Check Preferred Stock}

We partitioned the sample into four groups determined by the existence of poison pills and blank-check preferred stock. ${ }^{14}$ We focused particularly on poison pills and blank-check preferred stock for three reasons. First, a large number of firms use both provisions; second, both are significantly related to both $\mathrm{ROA}_{i, t}^{a}$ and $\mathrm{M} / \mathrm{B}_{i, t}^{a}$; and third, the incremental effect of each probably depends on the other, because a primary influence typically attributed to blank-check preferred stock is that it provides management with a vehicle to implement a poison pill. The interpretation of the results in Table 3 relies on

\footnotetext{
${ }^{13}$ As reported in Table 1 , only a small number of firms opted out of coverage by a state takeover law during the sample period. Beginning with an aggressive Pennsylvania antitakeover law passed in 1990, a larger number of firms have opted out of coverage by state laws since the end of the sample period. Pound (1990) found that firms opting out of the Pennsylvania law have slightly lower ROAs, but higher market values, than firms not opting out.

${ }^{14}$ In tests not reported here, we partitioned the sample according to several other provisions. The most important findings are reported here. Our partitioning procedure can be done for only a small number of provisions at a time. The number of ways $n$ provisions can be combined to create a unique governance structure is $2^{n}$. Our provisions, therefore, can be
} 
the assumption that each provision's effect on firm performance is linear and independent of other provisions. This assumption is likely to be violated, particularly for poison pills and blank-check preferred stock. Thus, the incremental effect of blank-check preferred stock may be smaller for firms that already have poison pills in place than for firms that do not.

Table 4 presents the average $\mathrm{ROA}_{i, t}^{a}$ and $\mathrm{M} / \mathrm{B}_{i, t}^{a}$ for each of the four groups, based on the presence or absence of poison pills and blank-check preferred stock. On average for the 1984-89 period, 77.7 firms a year had neither a poison pill nor blank-check preferred stock. The mean $\mathrm{ROA}_{i, t}^{a}$ for firms in this group is 0.2616 with a $t$-statistic of 7.84. The mean $\mathrm{M} / \mathrm{B}_{i, t}^{a}$ also is positive for this group- -0.3502 with a $t$-statistic of 10.53 . For firms having blank-check preferred stock but no poison pill, the performance measures are negative but not significantly different from zero (the mean $\mathrm{ROA}_{i, t}^{a}$ is -0.0158 with $t=-0.93$; the mean $\mathrm{M} / \mathrm{B}_{i, t}^{a}$ is -0.0233 with $t=-1.22$ ). Firms with poison pills, however, show significantly poorer performance than their industry peers. For firms having poison pills but no blank-check preferred stock, the mean $\operatorname{ROA}_{i, t}^{a}$ is -0.3965 with $t=-2.16$ and the mean $\mathrm{M} / \mathrm{B}_{i, t}^{a}$ is -0.2491 with $t=-1.48$. For firms having both poison pills and blank-check preferred stock, the mean $\operatorname{ROA}_{i, t}^{a}$ is -0.1643 with $t=-3.31$ and the mean $\mathrm{M} / \mathrm{B}_{i, t}^{a}$ is -0.2450 with $t=-3.22$.

These results indicate that firms with neither poison pills nor blank-check preferred stock are characterized by superior performance, on average. Although firms with just blank-check preferred stock perform poorly relative to this group, the poorest performance is among firms with poison pills. These results suggest that the incremental negative effect of a poison pill on $\mathrm{ROA}_{i, t}^{a}$ and $\mathrm{M} / \mathrm{B}_{i, t}^{a}$ is larger than that of blank-check preferred stock.

\section{Sensitivity Tests}

Data on the correlations between governance provisions and performance measures are presented in Tables 2 to 4 . Under the assumption that industry adjustment controls for other factors that lead firms to adopt the provisions, these results can be interpreted as tests of the managerial entrenchment and stockholders' interest hypotheses. This assumption may not be true, however. In particular, firms may adopt corporate governance provisions in response to financial performance; that is, the direction of causality may run from performance to provisions, not the other way around.

used to create $2^{20}=1,048,576$ unique governance structures. In our 1989 sample of 495 firms, we observed 320 unique combinations. By selecting just two provisions, we obtained a manageable number of groups. 


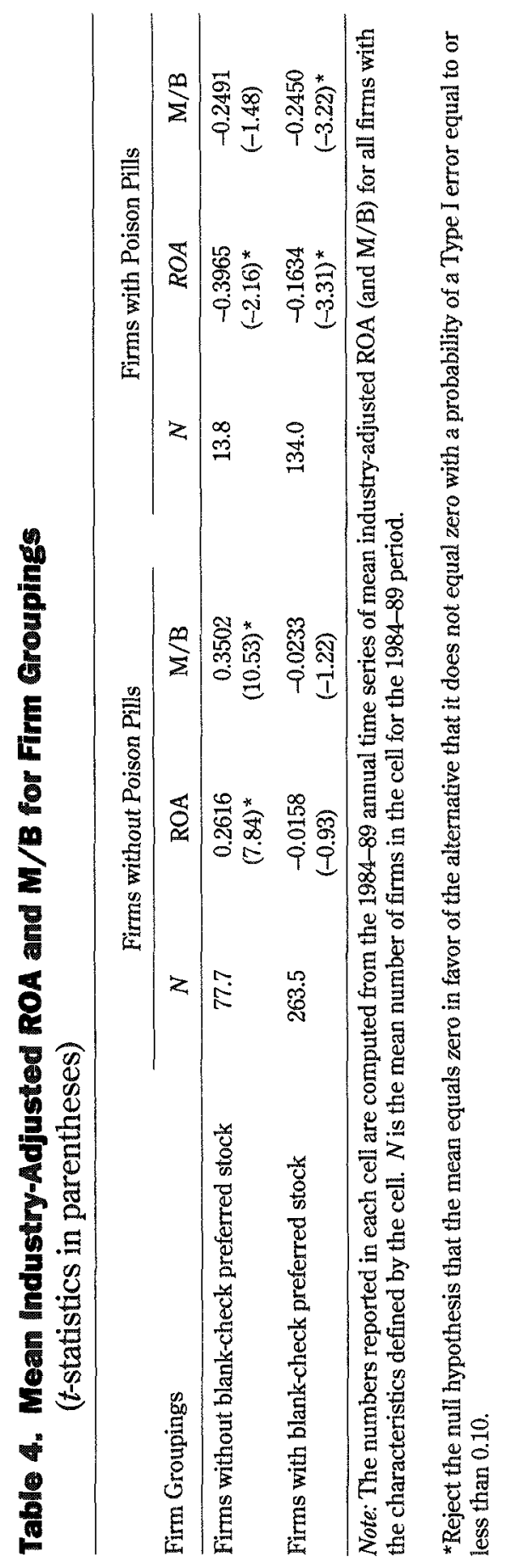


Causality . To test the direction of causality between performance and governance provisions, cross-sectional linear regressions with $\mathrm{ROA}_{i, t}^{a}$ and $\mathrm{M} / \mathrm{B}_{i, t}^{a}$ as the dependent variables were estimated for each year. Within each regression, each provision is associated with three mutually exclusive dummy variables. For a given year, the leading dummy is assigned a value of 1 if the firm currently does not have the provision but subsequently adopts it within two years. The contemporaneous dummy is assigned a value of 1 if the firm adopted the provision in the current year or in either of the prior two years. The lagged dummy is assigned a value of 1 if the firm adopted the provision more than two years ago.

Each of the dummy variables is industry adjusted, as described in Equation 2. With three dummy variables associated with each of 20 provisions, each annual cross-sectional regression has 60 governance regressors. Because the leading dummy variable requires a two-year lead in information on the corporate governance data, cross-sectional regressions are estimated only for the years in the 1984-87 period. The time series of cross-sectional estimators for each regressor is used to calculate a mean value, as in Equation 7.

The mean estimator for each leading dummy variable is used to test the hypothesis (stated in alternative form) that the provision was adopted in response to the firm's financial performance. The estimator for each contemporaneous dummy variable reflects the association between firm performance and a recently adopted provision. The estimator for each lagged dummy variable reflects the association between firm performance and the long-term presence of the governance provision. We interpreted the lagged variable estimators as reflecting the long-term effect of a provision on performance.

- Poison pill results. The results from this experiment are reported in Table 5. The most noteworthy results concern the effects of poison pills. The mean coefficients for the leading dummy variables are negative for both the $\mathrm{ROA}_{i, t}^{a}$ and $\mathrm{M} / \mathrm{B}_{i, t}^{a}$ regressions ( -0.0971 and -0.1367 , respectively). In both cases, however, the $t$-statistics are small. Also in both cases, the mean coefficients for the contemporaneous dummy variables are negative and statistically significant $(-0.1595$ with $t=-3.52$ and -0.2214 with $t=-3.19)$. The lagged dummy estimators are even larger in absolute value, with higher $t$-statistics $(-0.4124$ with $t=-5.22$ and -0.5965 with $t=-14.20)$. The results for the leading dummy variables indicate a small and statistically insignificant tendency for poorly performing firms to adopt poison pills within two years. The results for the contemporaneous and lagged dummy variables reveal much stronger associations between poor performance and the prior adoption of poison pills.

To investigate further the trend in correlation between performance and the presence of a poison pill, we computed the difference in the mean coeffi- 


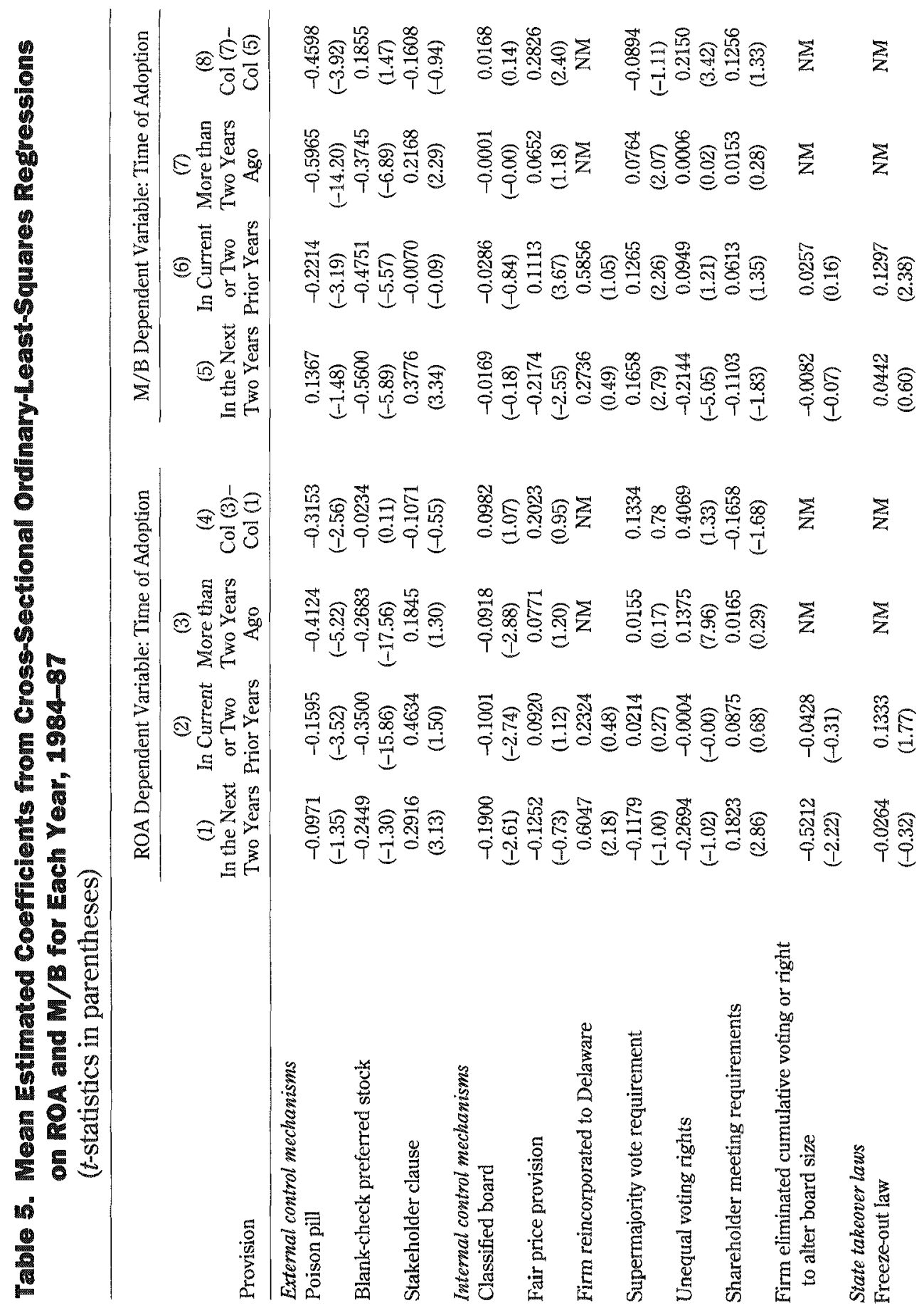




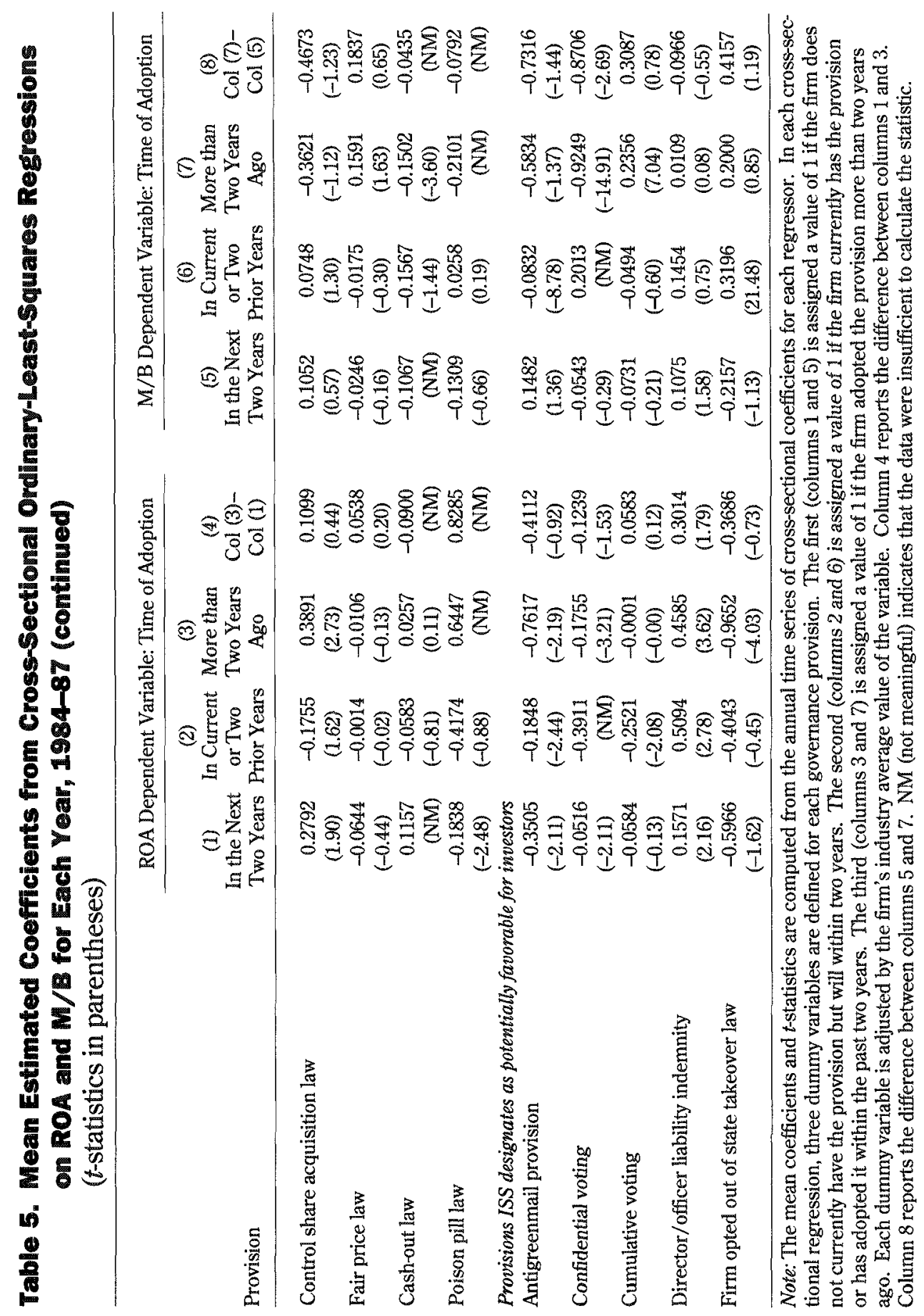


cients for the leading and lagged dummy variables. The $t$-statistic tests the null hypothesis that the mean coefficients are equal. ${ }^{15}$ For poison pills, the difference in the $\mathrm{ROA}_{i, t}^{a}$ coefficients is -0.3153 with $t=-2.56$; the difference in $\mathrm{M} / \mathrm{B}_{i, t}^{a}$ coefficients is -0.4598 with $t=-3.92$. This result indicates that the lagged dummy mean coefficient is lower than the mean leading dummy coefficient, implying that the negative correlation between the presence of a poison pill and firm performance is largest among firms that have had the pills for the longest time. Overall, these results are consistent with the hypothesis that poor financial performance follows the adoption of poison pills, not the other way around.

- Results for other provisions. Blank-check preferred stock is associated with poor performance, but the leading dummy variables shown in Table 5 are of roughly the same size as the contemporaneous and lagged dummy variables for both $\mathrm{ROA}_{i, t}^{a}$ and $\mathrm{M} / \mathrm{B}_{i, t}^{a}$, and the differences are not significantly different from zero. We interpreted these results as consistent with the hypothesis that poorly performing firms tend to adopt blank-check preferred stock but that the adoption is not associated with further performance declines.

The differences between the leading and lagged variables yield similar inferences about several other provisions. For example, stakeholder provisions are positively correlated with $\mathrm{ROA}_{i, t}^{a}$, but the Table 5 data indicate that this result reflects the fact that firms with high $\mathrm{ROA}_{i, t}^{a} s$ tend to adopt such provisions. Similarly, classified board and antigreenmail provisions both are negatively correlated with $\mathrm{ROA}_{i, t}^{a}$, primarily because these provisions tend to be adopted by firms with poor prior $\mathrm{ROA}_{i, t}^{a}$ performance. Supermajority vote requirements are positively related to $\mathrm{M} / \mathrm{B}_{i, t}^{a}$, primarily because these requirements tend to be adopted by firms with high $\mathrm{M} / \mathrm{B}_{i, t}^{a}$ values.

In several cases, a provision's correlation with performance differs significantly between firms soon to adopt the provision and those that have had the provision in place for more than two years. $\mathrm{M} / \mathrm{B}_{i, t}^{a}$ is negatively correlated with the pending adoption of a fair price provision $(-0.2174$ with $t=-2.55)$ but is positively correlated with such provisions when they are in place $(0.1113$ with $t=3.67$ ). This result is consistent with our earlier inference that fair price provisions are best characterized by the form of the stockholders' interest hypothesis in which the provision increases expected takeover premiums.

The results for unequal voting rights also are consistent with the stockholders' interest hypothesis. Table 3 reported that such rights are positively associated with $\mathrm{ROA}_{i, t}^{a}$ but not significantly related to $\mathrm{M} / \mathrm{B}_{i, t}^{a}$. The Table 5

\footnotetext{
${ }^{15}$ The $t$-statistic is computed on the difference in the means of the leading and lagged dummy variable estimators. See Mendenhall and Scheaffer (1973, pp. 345-46).
} 
results imply that the positive correlation with $\mathrm{ROA}_{i, t}^{a}$ derives from firms that have had unequal voting rights for more than two years. Furthermore, the correlation between $\mathrm{M} / \mathrm{B}_{i, t}^{a}$ and the presence of unequal voting rights for more than two years is significantly higher than in cases in which the unequal voting rights will be adopted within two years. These results are consistent with the hypothesis that unequal voting rights are associated with improvements in both $\mathrm{ROA}_{i, t}^{a}$ and $\mathrm{M} / \mathrm{B}_{i, t}^{a}$.

Table 4 showed that both $\mathrm{ROA}_{i, t}^{a}$ and $\mathrm{M} / \mathrm{B}_{i, t}^{a}$ are negatively correlated with the existence of confidential voting. The Table 5 results indicate that the negative correlation is strongest among firms that have had confidential voting for the longest times. These results are not consistent with arguments made by investor advocates who claim that confidential voting allows large shareholders to vote for performance-enhancing measures without fear of retaliation by incumbent managers. For example, United Shareholders of America, an investor advocacy organization, in 1992 lobbied for increased adoption of confidential voting provisions as a tool for making corporate governance procedures more "democratic."

Timing Assumption. We conducted several additional tests to investigate the sensitivity of our results to the timing and causality assumptions. Throughout, the data reveal the same patterns reported previously. First, firms with unusually few numbers of restrictive provisions have high mean values of $\mathrm{ROA}_{i, t}^{a}$ and $\mathrm{M} / \mathrm{B}_{i, t}^{a}$; second, the existence of a poison pill is associated with poor $\mathrm{ROA}_{i, t}^{a}$ and $\mathrm{M} / \mathrm{B}_{i, t}^{a}$ performance; and third, fair price provisions and unequal voting rights tend to be positively correlated with $\operatorname{ROA}_{i, t}^{a}$ and/or $\mathrm{M} / \mathrm{B}_{i, t}^{a}$. The correlations between $\mathrm{ROA}_{i, t}^{a}$ and $\mathrm{M} / \mathrm{B}_{i, t}^{a}$ and other individual governance provisions appear to be sensitive to the test specification.

As an example of one sensitivity test, Table 6 presents the results of tests that investigated the importance of the timing assumption in computing the corporate governance index. The assumption in earlier tests was that each provision's effect on $\mathrm{ROA}_{i, t}^{a}$ or $\mathrm{M} / \mathrm{B}_{i, t}^{a}$ begins in the year of adoption and is the same in all subsequent years. An alternative assumption is that $\mathrm{ROA}_{i, t}^{a}$ is first affected in the fiscal year following the year of adoption. A second alternative is that provisions do not affect reported financial performance until the second year after adoption.

The first column of Table 6 contains the overall mean $\mathrm{ROA}_{i, t}^{a}$ and $\mathrm{M} / \mathrm{B}_{i, t}^{a}$ for each corporate governance group under the original timing assumption. These results are identical to the results in Table 2 . The second and third columns report the results from similar tests using the other assumptions.

Overall, the results in Table 6 show that the timing assumption does not 


\section{Table 6. Mean Values of Industry-Adjusted ROA and M/B for Firms by Corporate Governance Index}

( $t$-statistics in parentheses)

\begin{tabular}{|c|c|c|c|}
\hline \multirow[b]{2}{*}{ Group } & \multicolumn{3}{|c|}{ Provisions Assumed to Affect ROA and M/B Beginning in the: } \\
\hline & $\begin{array}{c}\text { Year of } \\
\text { Adoption }^{a}\end{array}$ & $\begin{array}{l}\text { Year Following } \\
\text { Adoption }\end{array}$ & $\begin{array}{l}\text { Second Year after } \\
\text { Adoption }\end{array}$ \\
\hline \multicolumn{4}{|c|}{ Liberal governance structure $(-1.5>\mathrm{CGI} q, t)$} \\
\hline Mean number of firms & 83.2 & 86.3 & 86.0 \\
\hline \multirow[t]{2}{*}{ Mean industry-adjusted ROA } & 0.1497 & 0.1334 & 0.1178 \\
\hline & $(3.26)^{*}$ & $(3.84)^{*}$ & $(3.33)^{*}$ \\
\hline \multirow[t]{2}{*}{ Mean industry-adjusted $M / B$} & 0.2445 & 0.2563 & 0.2120 \\
\hline & $(6.94)^{*}$ & $(6.31)^{*}$ & $(5.18)^{*}$ \\
\hline \multicolumn{4}{|c|}{ Average governance structure $\left(1.5 \geq \mathrm{CGI}_{i, t}^{q} \geq-1.5\right)$} \\
\hline Mean number of firms & 315.3 & 315.5 & 315.0 \\
\hline \multirow[t]{2}{*}{ Mean industry-adjusted ROA } & -0.0233 & -0.0285 & -0.0140 \\
\hline & $(-1.93)$ & $(-2.55)^{*}$ & $(-1.40)$ \\
\hline \multirow[t]{2}{*}{ Mean industry-adjusted M/B } & -0.0630 & -0.0697 & -0.0501 \\
\hline & $(-4.87)^{*}$ & $(-7.31)^{*}$ & $(-17.02)^{*}$ \\
\hline \multicolumn{4}{|c|}{ Resirictive governance structure $\left(\mathrm{CGI}_{i, t}^{a}>1.5\right)$} \\
\hline Mean number of firms & 90.5 & 89.2 & 89.5 \\
\hline \multirow[t]{2}{*}{ Mean industry-adjusted ROA } & -0.0328 & -0.0159 & -0.0619 \\
\hline & $(-1.18)$ & $(-0.80)$ & $(-3.36)^{\star}$ \\
\hline \multirow{2}{*}{ Mean industry-adjusted $\mathrm{M} / \mathrm{B}$} & 0.0054 & 0.0121 & -0.0090 \\
\hline & $(0.13)$ & $(0.52)$ & $(-0.70)$ \\
\hline
\end{tabular}

Note: Means and $t$-statistics are computed from the time series of annual mean values within each category.

${ }^{a}$ Corporate governance index computed each year for the 1984-89 period, based on all provisions currently in place.

Index computed for each year for the 1985-90 period, based on all provisions that have been in place for at least one year.

'Index computed for each year for the 1986-91 period, based on all provisions that have been in place for at least two years.

${ }^{*}$ Reject the null hypothesis that the mean equals zero in favor of the alternative that it does not equal zero with a probability of a Type I error equal to or less than 0.10 .

significantly affect our inferences. Like those in Table 2 , the results in Table 6 are consistent with the managerial entrenchment hypothesis. Under all three timing assumptions, firms with relatively liberal governance structures have the highest mean $\mathrm{ROA}_{i, t}^{a} \mathrm{~s}$ and $\mathrm{M} / \mathrm{B}_{i, t}^{a} \mathrm{~s}$, and firms with average or restrictive governance structures have lower mean $\mathrm{ROA}_{i, t}^{a} \mathrm{~s}$ and $\mathrm{M} / \mathrm{B}_{i, t}^{a} \mathrm{~s}$. 


\section{Conclusions}

The results of our examination of the relations between corporate governance provisions and firm performance certainly reflect noisy data. ROA, for example, is affected by firm-specific accounting choices and policies that probably are not depicted by our control variables and regressors. In addition, our industry-adjustment procedure is most likely an imperfect way to deal with the fact that governance structure and firm performance are both determined endogenously within the competitive process.

Data Patterns. Despite the shortcomings noted above, the data do reveal several patterns that provide insight into the financial effects of a firm's overall governance structure.

- Corporate governance structure and firm performance. Firms with an unusually low number of restrictive governance provisions compared with other firms in their industries have the highest mean industry-adjusted ROAs and $\mathrm{M} / \mathrm{Bs}$. This result is consistent with the managerial entrenchment hypothesis, which holds that firms with liberal governance structures perform well because their managers are more accountable to shareholders and are more easily disciplined by market forces.

- Effects of specific governance provisions. Different corporate governance provisions are associated with firm performance in different ways. The most consistent findings regard the effects of poison pills, which are negatively correlated with both ROA and M/B. The evidence that, on average, poor performance leads to the adoption of a poison pill is weak; the evidence is much stronger that a negative correlation exists between poison pills and performance for recently adopted pills and pills that have been in place for more than two years. The strongest correlation is with pills that have been in place the longest. These results are consistent with the managerial entrenchment hypothesis, which implies that poison pills adversely affect firm performance.

The correlations between most other provisions and performance are not statistically significant or robust to specification changes. Two provisions, however, tend to be positively related to the performance measures. Unequal voting rights are positively related to both $R O A$ and $M / B$, suggesting that such rights serve stockholders' interests, on average. Fair-price charter amendments are positively correlated with $\mathrm{M} / \mathrm{B}$ but are not significantly correlated with ROA. These results are consistent with a second form of the stockholders' interest hypothesis, in which restrictive provisions do not affect current performance but yield higher expected takeover premiums.

- Poison pills versus blank-check preferred stock. Poison pills and blankcheck preferred stock both are negatively correlated with ROA and M/B. In 
a closer examination, however, the data indicate that poison pills have a larger incremental effect on current performance than does blank-check preferred stock. Firms with blank-check preferred stock but without poison pills have average measures of (industry-adjusted) ROA and M/B performance. Firms with poison pills-with or without blank-check preferred stock-strongly underperform their industry peers. Firms with neither poison pills nor blankcheck preferred stock have large positive mean industry-adjusted ROA and $\mathrm{M} / \mathrm{B}$.

An Ex Post Rationale. The results for poison pills and the results that measure the effect of a firm's overall governance structure are consistent with the managerial entrenchment hypothesis. The results for most other provisions, however, indicate that the relation between governance structure and financial performance is more complicated than posited by either the entrenchment or stockholders' interest hypotheses. We conjecture that different governance provisions constrain different sets of activities and have firm-specific effects on value. This conjecture is consistent with the mixed results from event studies about the effects of antitakeover provisions in general on stockholder wealth. For example, the announcements of some antitakeover charter provisions have insignificant average effects on firm value (DeAngelo and Rice 1983, Linn and McConnell 1983). Announcements of poison pills are associated with stock price declines, on average (e.g., Malatesta and Walkling 1988), but even this result is affected by firm-specific characteristics (Brickley et al. 1994, Comment and Schwert 1994).

These results suggest that certain types of insulation from the market for corporate control convey benefits to shareholders. Other types of insulation do not. Our evidence indicates that poison pills and very restrictive governance structures are associated with-and contribute to-poor financial performance. 


\section{Appendix. \\ Descriptions of \\ 20 Corporate \\ Governance Provisions}

\section{External Control Mechanisms}

- Poison pills. Poison pills are securities that entitle their holders to special rights if the issuing firm becomes the subject of a takeover bid. These rights substantially increase the cost to a bidder of acquiring control of the issuing firm without the cooperation of its incumbent management. In a typical case, the poison pill is established by issuing a special dividend in the form of a right to purchase additional shares of the issuing firm's common stock. The rights trade with the common shares until a triggering event such as an unsolicited takeover bid occurs. Then, the rights detach and may be exercised at a low price by shareholders other than the bidder. In most poison pills, rights-holders can purchase shares in the bidding company at low prices if the bidder acquires control of the issuing company.

Poison pills are also called "shareholders' rights plans." Although the specific provisions vary, all are designed to deter hostile bids. Managers typically have full discretion in determining whether to trigger a poison pill's provisions, subject to wide limits established by previous court decisions. Unlike antitakeover charter and bylaw amendments, poison pills are not submitted to shareholders for ratification. Requests to authorize large amounts of additional common or preferred stock, which must be approved by shareholders, frequently are a standby measure for companies that have adopted, or may adopt, poison pills.

- Blank-check preferred stock. Blank-check preferred stock is authorized preferred stock for which the board of directors has broad discretion to establish voting, dividend, conversion, and other rights. Blank-check preferred stock provides the board with financial flexibility, but it can also be used to establish or implement a poison pill. Blank-check preferred stock is thus a standby antitakeover measure for companies that have adopted or may adopt poison pills. It also can be issued to parties friendly to management to block 
unwanted hostile bids.

- Stakeholder clause. A stakeholder clause is a charter amendment that permits directors to consider the effects of their decision on constituencies other than stockholders. For example, directors may, or may be required to, evaluate the impact of a proposed change in control on employees, host communities, suppliers, and others. The clause provides a target company's board members with an explicit legal basis to reject takeover bids that are attractive to shareholders.

\section{Internal Control Mechanisms}

n Classified (or staggered) board. In a classified board, directors are divided into separate classes and elected to overlapping terms. For example, a firm with a three-class classified board would hold elections each year for one-third of the board seats, each with a three-year term. Because only one-third of the board can be replaced each year, a hostile bidder with voting control of the corporation may be unable to control the board for up to two years. Classifying the board also may deter proxy contests for control, because only one-third of the directors stand for elections in any one year.

- Fair price provision. A fair price provision requires a large shareholder to pay a price set by formula for all shares acquired in the back end of a two-tiered acquisition. Typically, the price to be paid is the highest price the shareholder paid for any shares acquired during the first stage of the acquisition. Most fair price provisions do not apply if the large shareholder's offer is approved by a target company's board or if the bidder obtains a specified supermajority level of approval from the target's shareholders. A fair price provision may increase a large shareholder's cost of obtaining additional shares. Because it regulates the price paid in a two-tiered offer, the provision may also discourage some takeover bids.

- Reincorporation to Delaware. Delaware corporate law is widely regarded as friendly to incumbent managers. Corporations can change their state of incorporation to strengthen their antitakeover defenses. The majority of firms in our sample identified as reincorporating in Delaware have moved from California, which requires cumulative voting and prohibits board classification. Delaware corporate law, in contrast, permits companies to choose whether to classify the board or to make cumulative voting available.

- Supermajority vote requirement. This requirement establishes a level of approval for specified actions that is higher than the minimum set by state law. Such provisions often establish approval levels of 75 or 85 percent for actions that otherwise would require majority approval. These requirements often exceed the level of shareholder participation at a meeting, making 
actions that require supermajority approval very costly. Supermajority provisions may apply to mergers, sales of assets, or other specified transactions. Those that apply to the amendment of bylaws or corporate charters often are referred to as lock-in provisions.

- Unequal voting rights. In general, these measures reduce the voting power of large outside shareholders and enhance the control of management, making hostile takeovers more costly. Under one typical plan, called a dualclass capitalization, two classes of stock exist, one with voting rights superior to the other. A second type of plan grants long-term stockholders super voting rights. A third unequal voting device, known as the substantial shareholder provision, reduces the voting power of the holder once a certain threshold of stock ownership has been reached.

- Shareholder meeting requirements. Meeting requirements are restrictions on either of two mechanisms that otherwise can be used to circumvent the normal corporate decision-making process. The first restriction is on the right to call special shareholder meetings. The second restriction is on the right to act by written consent, which enables shareholders with sufficient votes to take actions that otherwise would have to await a special or annual shareholder meeting. Both restrictions override default provisions in most states' incorporation statutes that permit special meetings or action by written consent. Both restrictions impede a large shareholder's ability to exercise its voting authority to implement quick changes in company policies or facilitate a change in control.

- Firm elimination of cumulative voting or right to alter board size. Cumulative voting permits shareholders to distribute their total votes in any fashion they desire among the nominees to a company's board. Each shareholder's total votes are equal to the number of shares held times the number of directors to be elected. By concentrating votes on selected candidates, minority shareholders can still elect a small number of representatives to the board. Minority shareholders, including those with large shareholdings, have a more difficult time electing their candidates to the boards of firms that have eliminated cumulative voting and replaced it with straight voting.

Similarly, some companies have adopted charter provisions that require supermajority votes among directors, shareholders, or both to alter the board size. Such provisions increase a large outside shareholder's cost of exercising authority to change corporate policy. In the absence of such a restriction, large outside shareholders could avoid other antitakeover restrictions by increasing the size of the board and packing the board with supporters. 


\section{State Takeover Laws}

Freeze-out law. Such laws prohibit a large shareholder from engaging in any business combination with the covered firm for a specified number of years unless approval is obtained from the target firm's directors before the bidder acquires more than a specified fraction of target shares. Even after the mandatory waiting period, most freeze-out laws allow the business combination to proceed only if the transaction satisfies fair price provisions. Thus, the typical freeze-out law is like a fair price law with a forced delay. The Delaware freeze-out law, adopted in 1988, covers a large number of corporations. It requires a three-year waiting period, although it permits business combinations during the freeze-out period that are approved by two-thirds of the voting stock not held by the interested shareholder. It also permits some business combinations with third parties, such as a sale of assets, during the freeze-out period.

- Control share acquisition law. This type of law requires shareholder approval before a large shareholder may vote shares obtained in a control share acquisition. A control share acquisition refers to an accumulation of shares to above a threshold level, for example, to one-fifth the outstanding shares of a covered corporation. Control share acquisition laws increase a bidder's cost of exercising voting rights. Some takeover experts, including Martin Lipton, regard such laws as relatively weak deterrents to hostile acquisitions because they permit shareholders effectively to vote on the proposed acquisition.

- Fair price law. These laws are similar to fair-price charter amendments adopted by many firms. They regulate the back-end price in a two-tiered takeover bid or other significant business combination involving a large shareholder. The typical fair price law prohibits business combinations between the firm and a large stockholder unless one of two conditions is met: (1) prior approval is granted by a supermajority (e.g., 80 percent) of all outstanding voting stock and by a supermajority (e.g., two-thirds) of the outstanding stock not held by the interested stockholder, or (2) stockholders receive a stipulated price for the stock acquired by the large stockholder as part of the business combination. The stipulated price is set by a formula that guarantees that the price paid is likely to be very high.

- Cash-out law. Under this law, any person who acquires a large stake (e.g., 20 percent) in a firm is required to notify all other shareholders of the acquisition. All other shareholders are then entitled to sell their shares to the acquirer at a price at least as high as the highest price the acquirer paid in the period during which the large shareholder acquired its shares. This law has been adopted by only three states and was rescinded by one state. 
- Poison pill law. Poison pill laws grant firms the right to adopt poison pill takeover defenses. These laws may be important because the right to use poison pill defenses is presumably more secure when explicitly authorized by statute and thus less likely to be limited by the courts.

\section{Provisions that ISS Designates as Potentially Favorable for Investors}

- Antigreenmail provision. Greenmail refers to an arrangement in which a company repurchases the stock held by a large shareholder, usually at an above-market price, in exchange for the shareholder's agreement not to launch a contest for control of the company for a specified time period. An antigreenmail provision prohibits a company's managers from entering such an agreement unless the repurchase offer is made to all shareholders on a pro rata basis or unless shareholders approve of the transaction. Antigreenmail provisions have an ambiguous effect on takeover deterrence. On the one hand, such a provision removes one takeover defense available to managers and decreases the cost to the holder of a large block of effecting a control change. On the other hand, the provision decreases a potential bidder's expected return from engaging in a control contest and, therefore, deters the accumulation of a large block of stock that often precedes a takeover attempt.

- Confidential voting. This provision establishes a procedure in which all proxies, ballots, and voting tabulations that identify individual shareholders are kept confidential. Only vote tabulators and election inspectors may examine individual proxies and ballots. Managers and shareholders are told only of vote totals. Confidential voting may protect shareholders, particularly large shareholders, from being subject to coercion or retaliatory measures from management for the shareholders' voting decisions.

- Cumulative voting. Cumulative voting permits shareholders to distribute their total votes in any fashion they desire among the nominees to a company's board. Each shareholder's vote total is equal to the number of shares held times the number of directors to be elected. By concentrating votes on selected candidates, minority shareholders still can elect a small number of representatives to the board. Cumulative voting may facilitate outside shareholders' attempts to influence company policies by gaining representation on the board.

Director/officer liability indemnity. This indemnity occurs when the corporation adopts a provision in which it promises to reimburse its directors and/or top officers for legal expenses, damages, and judgments incurred as a result of any lawsuit relating to the directors' and officers' corporate actions. In virtually all cases, firms that adopt such a provision purchase indemnity 
insurance to cover their risk. In some cases, providers of indemnity insurance refuse to cover poorly performing firms. Such firms do not adopt indemnity provisions.

- Firm opted out of state takeover law. Some state takeover laws contain language that allows affected companies not to be covered by part or all of the law's provisions. Firms that have taken steps not to be covered by a state takeover law are identified in the sample. 


\section{References}

Alexander, John C., M. Wayne Marr, and Michael F. Spivey. 1993. "State Constituency Statutes and Firm Value: An Empirical Examination." Clemson University working paper.

Bhagat, Sanjai, and Richard H. Jeffries. 1991. "Voting Power in the Proxy Process: The Case of Antitakeover Charter Amendments." Journal of Financial Economics, vol. 30:193-226.

Bhagat, Sanjai, and Richard H. Jeffries, Jr. 1994. "The Causes and Consequences of Takeover Defense: Evidence from Greenmail." Journal of Corporate Finance (forthcoming).

Brickley, James A., Jeffrey L. Coles, and Rory L. Terry. 1994. "Outside Directors and the Adoption of Poison Pills." Journal of Financial Economics, vol. 35, no. 3:371-90.

Brook, Yaron, and Ramesh K.S. Rao. 1994. "Shareholder Wealth Effects of Directors' AbilityLimitation Provisions." Journal of Financial and Quantitative Analysis, vol. 29, no. 3:481-97.

Bruner, Robert F. 1991. The Poison Pill Anti-Takeover Defense: The Price of Strategic Deterrence. Charlottesville, Va.: The Research Foundation of the Institute of Chartered Financial Analysts.

Comment, Robert, and William G. Schwert. 1994. "Poison or Placebo? Evidence on the Deterrent and Wealth Effects of Modern Antitakeover Measures." Joumal of Financial Economics (forthcoming).

DeAngelo, Harry, and Edward M. Rice. 1983. "Antitakeover Charter Amendments and Stockholder Wealth." Journal of Financial Economics, vol. 11:329-60.

Demsetz, Harold, and Ken Lehn. 1985. "The Structure of Corporate Ownership: Causes and Consequences." Joumal of Political Economy, vol. 93:1155-77.

Eckbo, B. Espen. 1990. "Valuation Effects of Greenmail Prohibitions." Joumal of Financial and Quantitative Analysis. vol. 25:491-505.

Gordon, Lilli A 1993. Active Investing in the U.S. Equity Market: Past Performance and Future Prospects. Report to the California Public Employees' Retirement System, January 11.

Gordon, Lilli, and John Pound. 1992. "Governance Matters: An Empirical Study of the Relationship between Corporate Governance and Corporate Performance." Harvard University working paper.

Hirschey, Mark, and Elaine Jones. 1993. "Long-Term Implications of Shark Repellent Adoptions." University of Kansas working paper.

Jarrell, Gregg A., and Annette B. Poulsen. 1987. "Shark Repellents and Stock Prices: The Effects of Antitakeover Amendments since 1980." Journal of Financial Economics, vol. 19:127-68.

Karpoff, Jonathan M., and Paul H. Malatesta. 1989. "The Wealth Effects of Second-Generation State Takeover Legislation." Journal of Financial Economics, vol. 25:291-322.

Linn, Scott C., and John J. McConnell. 1983. "An Empirical Examination of the Impact of Antitakeover Amendments on Common Stock Prices." Journal of Financial Economics, vol. 11:361-99.

Lipton, Martin, and Steven A. Rosenblum. 1991. "A New System of Corporate Governance: The Quinquennial Election of Directors." University of Chicago Law Review, vol. 58:187-253. 
Malatesta, Paul H., and Ralph A. Walkling. 1988. "Poison Pill Securities: Stockholder Wealth, Profitability, and Ownership Structure." Joumal of Financial Economics, vol. 20:347-76.

Manne, Henry G. 1965. "Mergers and the Market for Corporate Control." Journal of Political Economy, vol. 73:110-20.

Mendenhall, William, and Richard L. Scheaffer. 1973. Mathematical Statistics with Applications. North Scituate, Mass.: Duxberry Press.

McGurn, Patrick S., Sharon Pamepinto, and Adam B. Spector. 1992. "State Takeover Laws." Washington, D.C.: Investor Responsibility Research Center.

Pound, John. 1990. "On the Motives for Choosing a Corporate Governance Structure." Harvard University working paper.

Pound, John, and Gregg Jarrell. 1988. "Hostile Takeovers and the Regulatory Dilemma: Twenty-Five Years of Debate." Midland Corporate Finance Journal, vol. 5, no. 2:24-38.

Ryngaert, Michael. 1988. "The Effect of Poison Pill Securities on Shareholder Wealth." Journal of Financial Economics, vol. 20:377-417.

Wallman, Steven M.H. 1990. "The Corporate Constituency Concept: Rationales and Benefits." Covington and Burling working paper, Washington, D.C., July 11. 